\title{
Land Mines Conflict Dispute in Southeast Sulawesi Indonesia
}

\author{
Syahbuddin and Muhammad Sjaiful \\ Faculty of Law, Halu Oleo University, Kendari, Southeast Sulawesi, Indonesia
}

\begin{abstract}
Since the year 2010 to 2013 in the Province of Southeast Sulawesi has been reported that some areas have mining potential is fantastic. Some of the areas mentioned, among others, in Bombana, Kolaka, Konawe North, and South Konawe, have found a few spots that the area has the potential for very rich mining resources, such as gold, nickel, and marble. Although some areas in the Southeast Sulawesi, has very promising prospects for improvement of the welfare of society as a whole and with the discovery of areas that store relatively abundant mining resources, but the social reality shows that the existence of several areas of social conflict is still storing that at any time can swelled so of course lead to a variety of vulnerabilities, among others, could disrupt regional security, as well as interfere with the stability of society in the midst of a pluralistic nation of Indonesia. Conflict is rife, including mining land dispute between local communities landowners venue for mining activities with mining enterprise manager. Of the many conflicts that erupted, it is not uncommon implications for anarchism action undertaken by local groups against property owned mining enterprises, including the attack on offices belonging to local governments suspected by earlier groups did not provide the right solutions that favor the local community disputes relating to land mines. Based on this reality, the conflict dispute method for context mining lands of Southeast Sulawesi properly with non-litigation approach that characterized the appropriate wisdom legal culture of Southeast Sulawesi local residents, which is the conflict in a sensible decision as to minimize social conflict is prolonged, so as to avoid bloodshed or loss of life and property is both material and immaterial. This research is very vital in order to anticipate the outbreak of horizontal conflicts that threaten regional security in Southeast Sulawesi.
\end{abstract}

Keywords: Local Community, Mining Company, Non-Litigate Dispute Resolution

\section{Introduction}

Since the year 2010 to 2012 in Southeast Sulawesi province, it has been reported that some areas have mining potential is fantastic. Some of the areas which may be mentioned, among others, in which the Bombana in the region have found some spots that the area has the potential for very rich mining resources, such as the potential for gold, nickel, and marble.

Despite some point in Southeast Sulawesi mining area, has a very promising prospect for improving the welfare of society as a whole, with the discovery of areas that store relatively abundant mining resources, such as gold, nickel, and marble. But the social reality shows that the existence of some areas is still storing social conflicts could erupt at any moment so of course lead to a variety of vulnerabilities, among others, can disrupt social stability in the midst of national and state are diverse and pluralistic. Widespread social conflicts currently taking place with regard to the control and management of the mining area in Southeast Sulawesi, namely mining land conflicts between local people versus government versus regional or local public enterprises engaged in the exploitation and exploration of mining.

During this ongoing land conflicts between local communities versus local government or mining companies completed using the court institutions. This method is a legal step to mediate the impasse in the case of conflicts between local communities dealing with the government or Integration mine. But the way, actually is not very effective, in addition to the process is very long, costly high enough, also important is the court decision always results in a decision to be lost or won. In effect, there will always be discontent between the two sides in conflict.
Dissatisfaction of one of the parties of the court's decision, certainly very prone pose new problems, such as action potential new anarchism likely sticking as a result of dissatisfaction with one of the parties to court decisions issued. For this reason, it is true; there should be alternative dispute resolution other than court sleeked at risk. Dispute resolution path is the path of dispute resolution is reached by the path of non-litigation dispute resolution is not in court but outside the court pathway mechanisms, which involve a more credible mediator to find solutions that are a compromise between the two sides dispute which resulted in the decision that gives satisfaction of both parties. On this basis, this paper concentrates to reveal the urgency as well as academically appropriate procedures wisdom legal culture of Southeast Sulawesi residents of local communities and the concept of security and defense, involving non-litigation dispute resolution to the land dispute involving the local community, which is a wise decision as to minimize protracted social conflict so as not to cause bloodshed or loss of life and property is both material and immaterial. The urgency of the use of non-litigation dispute resolution in order to resolve the conflict of land mines involving local communities in the Southeast Sulawesi. Models of nonlitigation dispute resolution so as not to trigger a comprehensive mining protracted land conflicts.

\section{Literature Review}

\section{Definition of Conflict}

The term conflict or dispute the language according to Indonesian Dictionary is anything that causes disagreement, dissension or discord. Under these terms, the conflict or dispute is with something that causes disagreement between two or more parties about something matter. Conflict or dispute in the opinion of Joses Jimmy Sembiring (2011)

Volume 4 Issue 12, Desember 2015 


\section{International Journal of Science and Research (IJSR) \\ ISSN (Online): 2319-7064}

Index Copernicus Value (2013): 6.14 | Impact Factor (2014): 5.611

occurs because of a difference of opinion or perception or misunderstanding which is a depiction of the conscious environments based on one understands.

Similarly, the term disputes or conflicts derived from the English term, that of the conflict or dispute John Echols and Hasas Sadily (2003). The term, basically contain the same sense that the difference in interest between the two parties or more, however, differ in terms of both Indonesian in terms of uptake. Conflict in the Indonesian absorbed into the conflict while the dispute is translated by the word Disputes Mahrudin (2010).

Based on the explanation of these two terms, the most among legal writers equate the use of the term conflicts with the terms of dispute as the two terms have the same meaning. Thus, disputes or conflicts can be interpreted as a dispute between two or more parties who feel aggrieved with each other so that the path of the parties or the court deliberation to resolve disputes or differences that occur Sarjita (2005).

\section{The concept of Non-Litigation Dispute Resolution}

Almost in every region in Indonesia which are land disputes, the parties concerned and the authority to handle these problems resolve in various ways. Means of dispute resolution that have been taken so far is through the courts (litigation) and the resolution of disputes outside the court (non-litigation) Bambang Sutiyoso (2008).

Judicial settlement aims to get justice and the rule of law, and then the court settlement is preferred instead of peace in resolving a dispute between the parties in dispute and not looking right or wrong. When you have to find who's right and wrong will not result in a favorable decision by the parties to the dispute. Non-litigation dispute resolution or alternative better known as Alternative Dispute Resolution (ADR) is regulated in Law No. 9 of 1999 on Arbitration and ADR Nevey Ariani (2012). Dispute resolution mechanisms in this way are classified in non-litigation media is a concept of conflict resolution or dispute cooperative agreement aimed at a solution to the conflict or dispute is a win-win solution. ADR was developed by legal practitioners and academics as a means of dispute resolution that they have more access to justice Rachmadi Usman (2003).

\section{Research Method}

Research methods use qualitative approach; it was done in schools and Vocational Education and the Ministry and Cultural Kendari. This paper uses qualitative methods. Bryman (1988) and Sugiyono (2012) argue that qualitative research is the collection of data on a natural background, using natural methods, and performed by a person or researchers who are interested in nature. Qualitative research by Jane Richie is an attempt to present the social world, and perspectives in the world, in terms of concept, behavior, perception and the question of human studied.

Finch (1986) looked at as a qualitative research approach to uncover the meanings and contexts of individual behavior. Qualitative and quantitative approaches differ not only in terms of the methods used but also on the perception of the problem and the type of data that is generated. Norman Denzin and Yonna Lincoln (2009) quotes Patton, Michael Quinn (1990) add that the data collection instruments provide benefits, where he can be flexible and adaptive and can use its entirety senses to understand something. Thus, the instruments in this study are human instrument.

\section{Results and Discussion}

\section{Origin of Mining Land Conflict in Southeast Sulawesi}

The discovery of land mines in the Southeast was started in 2008 when a group of people who exist in the District area Rumbia-Rarowatu fined a parcel of land located in the village plantation Wumbubangka District of North Rarowatu which contained gold. So also the people who are around the River Tahi Ite have found several areas in around the river that turns Tahi Ite granulated sand containing gold.

The issue then is spread in almost are by and large the people of Southeast Sulawesi, that in Bombana gold grains contain relatively abundant. This issue was also later led to droves of existing communities in the Southeast, including some who came from other parts of Indonesia to the region Bombana to scavenge gold granules. What is described by the researchers, reinforced by Abraham and Mother Engki Raden, community leaders Bombana on interviews with writer dated 2 September 2013 as follows:

"Around July 2008, news spread about the discovery of the region in the area and the River Mole Rarowatu Ite in Bombana containing gold. This issue spread that ultimately known by many people both in Southeast Sulawesi and in some parts of Indonesia. In the end, people came in droves to meet Bombana region just to earn gold. When we see, all the people in Bombana seems tempted to scavenge or find gold. Impact when it is, the district capital became deserted with economic activity, such as markets become quiet, most farmers are reluctant to cultivate their fields, even some of the staff employees there are rarely in the office, all tempted to hunt or scavenge gold. The economy of the district capital actually kinda lame that result in the cost of basic needs of society at Nine Bombana. All that is triggered because the public's desire to mine gold".

The rise in the gold mining Bombana as writer interviews to the respondents as well as economic impact. Goods price index to be increased which was followed by shortages of goods for the needs of the economy. About how society conducts processing or making gold in the region, based on interviews with the Head of Legal Researchers Regional Secretariat Bombana Kalvarious Syamsruth, in general traditionally done manually or by means of a traditional pan. It was revealed from the results of interviews with researchers, 2 September 2013 as the following:

"At the time of hearing the issue of gold deposits in the region Bombana, then the people flocked to mine gold. In general, people who do the mining, is the traditional way to wash manually. The way the people digging area or areas suspected to contain gold. Excavation of sand and collected in a particular skillet then shake for a few 


\section{International Journal of Science and Research (IJSR) \\ ISSN (Online): 2319-7064}

Index Copernicus Value (2013): 6.14 | Impact Factor (2014): 5.611

minutes until the collected grains of sand containing gold which is then separated with a grain of sand. To separate them is usually by using mercury. Gold grains are then collected and forged or burned on a certain degree of temperature to solidify the gold grains to become a gold bar".

However, according to respondents, the behavior of the people who do the gold panning in the traditional manual, very serious impact on the environment, especially the Watershed (DAS) and excavated soils. Impact, among others, the watershed becomes easy widened resulting flooding and landslides feared erosion that endanger certain land areas.

Concerns from traditional gold mining in the area uncontrollable Bombana the impact on the economy and society Bombana circumstances, then the reason for the Government to Bombana to curb illegal mining was done. Bombana district government then instructed the traditional miners who came the necessity for a permit from the government official about to do mine. Permission is also granted to only certain areas are allowed to mine the traditional manually. Over time, the issue of gold mining in Bombana, heard by investors who are outside. At last comes the two investors is Fredie Tan and Leo Chandra Edward under the flag of PT Panca Metal to Bombana interest for exploration and exploitation of gold mining.

After both the investor to get permission to do the exploration and exploitation of gold mining in Bombana, the next steps are still constrained for them is a place for exploration and exploitation of which are by and large where the land is still owned land belonging to indigenous peoples into 8 (eight ) family clumps, each clump include:

1) Family clumps Tandole / Munara;

2) Family clumps Aoote/Irai;

3) Family clumps Pimpie

4) Family clumps I Maloa;

5) Family clumps I Rente;

6) Family clumps I Riu;

7) Family clumps Sangia Nilemba;

8) Family clumps Lauru.

Eight clumps of the family who has a collection of over 100 heads of household who are local landowners gold mining land site located in the village Wumbubangka, District of North Rarowatu, Bombana Southeast Sulawesi. Based on interviews the author on September 2, 2013 by Abd Latif Haba, Community leaders who represent and act as Chairman of 8 (eight) clumps family of the owner, said that the location of the land where gold mining is, a location / land formerly used for hunting, the maintenance livestock such as cattle, buffalo, and horses, as well as a plantation. Their area is approximately 5 hectares or $5000 \mathrm{~m}^{2}$.

To overcome the constraints faced by PT Panca Logam in terms of gold mining with landowners who are members of 8 (eight) clumps Moronene family, then made an agreement on production sharing agreements as well as a location which may be made between PT Panca Logam mining with land owners, which was made on January 20, 2009 According to Abd Latif Haba, the agreement between the 8 family grove landowners mine Makmur and PT Panca Logam in principle regulate three important things that:

1) Production Sharing Agreement on the acquisition of gold mining between the land owner and PT Panca Metals, namely, the net result of the company gets $80 \%$ and the land owners get a share of $20 \%$;

2) Mining company gets the full right to manage land mines along which allows intended to contain potential gold mine;

3) In the event of a dispute regarding the implementation of the agreement then is a discussion by pointing to the mediation team appointed by both parties.

Such a written agreement between the miners and landowners, who in the treaty format placed four witnesses, respectively: (1). Muh. Subhan Tambera; (2). Augustine Powatu; (3). Dirman Waate; (4). Dawondu Munara.

According to Abd Latif Haba, implementation of the agreement at first went smoothly and kept by the PT Panca Logam Makmur. However, when the body of PT Panca Logam Makmur internal conflicts shareholders, the implementation of the agreement is no longer fulfilled by the company. The breach of contract (default) conducted by the company, among other things:

1) The company has been negligent promise to pay $20 \%$ of the results contained in the agreement;

2) The company has exploration and exploitation of gold mines outside the land that has been agreed.

Abd Latif Haba in an interview with the researchers suggested that the family grove as the owner of the land have done a summons to the manager to keep the contents of the agreement, especially regarding the rights of $20 \%$ quota for the results to be accepted by the landowners. But it's still not responded to the summons by the PT Panca Logam Makmur especially since internal conflicts between landowners.

Breach of contract committed by the PT Panca Logam Makmur which then have an impact on the occurrence of conflicts with land owners, in turn continues to do the revision of the agreement between the owners of the land with the new management of PT Panca Logam Makmur is RJ Soehandoyo. Revised agreement is only done on matters relating to the portion of the results on the first agreement dated January 20,2009, the portion of the land owner gets $20 \%$, but in the second agreement, a new version of the board RJ Soehandoyo, the land owner gets a portion of Rp. 250, 000, 000, - (two hundred and fifty million rupiahs), which was signed by both parties on March 7, 2012.

According to Abd Latif Haba, to date the PT Panca Metal Makmur as processing gold mining areas in its position as the second party in the agreement made by both parties to be signed by the new board RJ Soehandoyo, not yet implemented. Respondents said the land owner as follows:

"Once we were out of the grove owners where I as a representative of the owners of the land only by a promise to the company to get a share of revenue as mentioned in the agreement, which to this day has not been realized. I repeatedly asked the company to realize the promise but always never materialized. There is a possibility that if the company does not want the family

\section{Volume 4 Issue 12, Desember 2015}




\section{International Journal of Science and Research (IJSR) \\ ISSN (Online): 2319-7064}

Index Copernicus Value (2013): 6.14 | Impact Factor (2014): 5.611

keep its promise then surely the family will be forced to act to the company, only we still refrain".

Based on these descriptions, the main node of land conflicts between land owners with companies in the mining processing Bombana include default (broken promises) made by the company to the owner of the land in terms of share of revenue as defined in the agreement between the two.

Mining land conflicts between land owners with mining companies that also emerged was a mining area which is wholly owned by the absolute miners, which according to the respondent landowners there are some areas that should not be explored and exploited, but still it was not be ignored agreement by the processing company mine. Results of interviews with Abdul Latif Haba, revealed the following:

"We have agreed with the company that Makmur PT Panca Metals mined by the company only to the extent of 2000 $\mathrm{m}^{2}$ area of $5000 \mathrm{~m}^{2}$ area suspected to contain gold. But even a broken promise by the company to mine even in areas outside the agreement".

It can be concluded that land conflicts also sparked a dispute between the owner of the land by mining companies is a violation of the PT Panca Metal Makmur to the areas agreed upon between both parties.

Urgency Use of Non-Litigation Dispute Resolution in the Context of Land Management Mining Conflicts Involving Local Communities

Mining land dispute that erupted in the region of Southeast Sulawesi province to take up studies at Bombana is an issue that is not only a crucial impact on land management but also to social stability. Social instability in the context of Indonesia's diverse society can certainly have a serious impact on the defense and security disturbances. In the context of security defense into the idea of the universe as the Defense Security adopted by the Nation of Indonesia as defined in Article 30 Amendment IV of the Constitution of 1945 states that the defense and security of the country is carried out through a system of defense and security of the people of the universe by the Indonesian military and the Indonesian National Police, as the main force, and the people, as a supporting force.

In this connection, horizontal conflicts that erupted in several areas of the country such as the events of disputes between warring tribes, regions or countries, then of course the Indonesian people through the perspective of security and defense doctrine of the universe, it is important to seriously consider doing the defense and security countries not only through the role of the TNI (Indonesian Armed Forces) but also involves all the components such as the police, as the first line of defense with the power of the people as a line of support. In that context, the Indonesian army and police acting as defense and security of the country in the field (directly involved) and the people's support morally and in other ways that can be done indirectly by each part, the balance will be realized in a variety of national defense aspect. So if the horizontal conflicts allowed to drag on without any quick and responsive handling, it is feared may have implications both directly and indirectly the presence of certain parties to conduct domestic Indonesian infiltration by utilizing the existing chaos in the community. These conditions certainly very worrying in the perspective of security and defense doctrine of the universe.

Similarly, mining land conflicts that erupted lately in Southeast Sulawesi it is possible to defense and national security dangers. That is, mining land conflicts involving local communities on the other hand can lure those who want to "disturb" the condition of the people who are in conflict with mining company's managers.

In conflict theory written some experts, said that the conflict in some places would be a "fertile ground" for the conspirators to take advantage pragmatic. Certainly in perspective Indonesia using universal security and defense doctrine, conflicts involving local communities in the case of land mines in Indonesia should be taken seriously because it is very likely to lead to social disintegration, which in turn triggered the disintegration that is very harmful to the integrity of the Unitary State of the Republic Indonesia.

In records National Planning Agency Indonesia 2012 is also noted on the possibilities of horizontal conflicts that could jeopardize the integrity of the premises as follows:

"Internally the military need to rebuild awareness constantly, that the main task of the military is facing the possibility of a real threat to the territorial integrity and sovereignty of the country, especially coming from a foreign power. Another challenge is the cultivation of the values of pride and passion for the role, both for civil society and for the soldiers as well as meeting the needs of military defense equipment. This would be achieved by continuously developing the strength and ability of the military to be able to carry out their roles and functions well. In addition, also expected to be built a military institution that has the effect of vibration or antidote (deterrence effect) against an enemy or potential enemy, thereby building images that combat capable military power at high effective. This has become one of the important factors in supporting the success of efforts to safeguard the sovereignty and security of the country and diplomacy in foreign relations".

"In addition, the level of public awareness of their rights and the free flow of information is higher in the era of transparency and democratization process, making all forms of injustice, inequality, and various forms of corruption, may soon be known as it is. If the law cannot be enforced equitably to overcome these problems, it can lead to dissatisfaction among the public, which in turn will lead to the emergence of anarchist actions, so as to cause disruption of public order and safety and security in the country. Therefore, it is necessary to build an effective police service, efficient and accountable to address the issues of law violation occurred, through various methodologies, tactics, and techniques based on law to uphold human rights".

Based on the observations of writer to disputes mining land conflicts involving local communities in Southeast Sulawesi Bombana, usually solved by using a path that is by using institutions litigation court. However, using a dispute

\section{Volume 4 Issue 12, Desember 2015}




\section{International Journal of Science and Research (IJSR) \\ ISSN (Online): 2319-7064}

Index Copernicus Value (2013): 6.14 | Impact Factor (2014): 5.611

resolution institutions such courts have not provided optimal results that satisfy both parties. Because the concept of dispute resolution litigation path only give decisions that are lose or win (win or lose) moreover there is no authority which could secure a permanent court decision is. So in fact, the court decision to be implemented at the level still faces obstacles, especially sociological rejection of people who do not want to accept the decision of the court itself.

In connection with that, the idea of mining land dispute resolution institutions using non-litigation dispute resolution, is very urgent considering this concept in addition to offering decision is a win-win approach to dispute resolution also emphasizes the cultural approach, socio-religious.

Based on observations of the behavior of researchers Bombana culture of Southeast Sulawesi, it appears that the tendency of society Bombana Southeast Sulawesi who live in the outskirts surrounding the urban area are more likely to resolve a dispute between them through customs and cultural approaches. That is, the choice of dispute resolution institutions with the tendency of non-litigation involving traditional leaders, religious leaders, or community leaders. For example, indigenous peoples Tolaki in the resolution of conflicts between them prefer the customary approach through symbols kalosara or Kabaena island community that is in dispute settlement Bombana symbol using the symbol totoro'a.

What the writer noted, is becoming important to put the mining settlement of land disputes between local land owners with the company operating the mine with the use of nonlitigation institutions. However, the use of non-litigation institutions within the framework of maintaining the integrity of the Republic should be concerned with not forgetting approach to defense and security. Dispute resolution with this approach is important is the framework for preventing the spread of conflicts that impact reach a point of escalation chaos to be a systemic effect that leads to the Tribe issues, Race, and Religion (SARA) as occurs in the case of Ambon and Poso. Depth of mining land conflicts in Southeast Sulawesi region which feared escalation can erupt to the point of endangering the security of the state of chaos that Indonesia must be prevented early on that the goal is none other than to keep the integrity of the Republic with a pluralistic composition of society.

Urgency mining land dispute resolution through the use of instruments in the context of non-litigation Southeast Sulawesi is very precise and immediate to be done but the framework is based approach to defense and security of the universe as the doctrine in the conception of the defense and security of the nation of Indonesia. As mentioned in the nations defense doctrine issued by the TNI Headquarters in 2012:

"Doctrine of National Defense has significance, i.e., as a guide in the management and conduct of national defense systems. At the strategic level, the State Defense Doctrine serves to create a defense system that is universal, both in peacetime and at war. Within the framework of the national defense, the essence of the State Defense Doctrine is a framework for the conduct of the defense in the military and defense synergy nirmiliter defense in an integrated, focused and continued as a single unified national defense and integral".

Based on the conception of the basic principle of nonlitigation dispute resolution still refers to the approach of Defense doctrine of Indonesia. Because the doctrine of national defense and security should also be characteristic in the handling of conflicts that took place in the frame of the Unitary State of Indonesia.

\section{Models of Non-Litigation Dispute Resolution Dispute against Land Mines in Southeast Sulawesi}

In the context of dispute resolution in non-conflict litigation against land mines in Southeast Sulawesi, and with reference to the behavior observations legal residents of Southeast Sulawesi by taking Bombana study. According to the authors, a model of non-litigation dispute resolution is more appropriate to use the instrument of mediation.

Mediation mechanism can be done by involving four groups as the most important element to resolve the conflict that erupted in a dispute over mining land. The first group is the group owner of the land, the second group is a group company operating the mine, and the third group is a group of community leaders who are credible and recognized stature by the local community. Equally important also is the group policy authority district government officials and security forces at the level of the Indonesian Armed Forces and the Indonesian Police.

This community leaders, facilitated by policy authorities do fail consultation (in mediation) to bring the parties to the dispute is between community group's landowners with Management Company mine (land mine). The position of public figure in question is very important because they are the most knowledgeable and very competent to understand the psychological and cultural conditions of the local community in terms of understanding the rights of ownership of the land under customary law applicable local. As concerns the presence of the security forces (Army-Police) is within the framework of the strategic role advising the defense and security of the universe approach to the conflict between the lands owners faced with a mining company.

According to the observations of the writer, the presence of military and police as an integral part in this dispute resolution models, will greatly influence the binding force of the decision issued in the mediation process itself. Because for now the cultural, military and police institutions still have a fairly strong influence by the respected Indonesian society in general.

In addition, according to my argument, strengthening the results deal a solution for resolving disputes between local land conflicts with mining companies should be stated in the form of a written agreement with legalized by a notary officer. Agreement set forth in writing the very least, would effectively be a power law can be binding on both parties in the conduct set forth in a written agreement.

\section{Volume 4 Issue 12, Desember 2015}




\section{Conclusion}

Based on the discussion of this paper, it is necessary to have conflict resolution mechanisms with the mining land-based defense and security approach that utilizes the local knowledge while accommodating the values of spirituality and religiosity. The dispute settlement mechanism of the model-based non-litigation defense a comprehensive universe that does not trigger land mines prolonged conflict, namely the dispute resolution mechanisms using mediation institution in which not only involve public figures but also involve other law enforcement officers.

\section{References}

[1] Achmad Chomzah, Ali (2003), Series III Land Law Dispute Settlement Land Rights and Land Law Series IV Land Acquisition Government Agencies, Achievement Book, Jakarta.

[2] Bambang Sutiyoso (2008), Business Dispute Settlement through on Line Dispute Resolution and force in Indonesia, Pulpit Law, Vol. 20 (2), Yogyakarta, pp. 232-234.

[3] Finch, J., 1986. Research and Policy: The uses of Qualitative Methods in Social and Educational Research, London: Falmer.

[4] John M Echols and Hasas Sadily (2003), English Dictionary Indonesia, Publisher Gramedia, Jakarta.

[5] Mahrudin (2010), Mining Policy Conflict between Government and Society in Buton, Government Studies Journal, Vol. 1 (1), 2010, pp Yogyakarta. 192.

[6] Nevey Varida Ariani, (2012) Alternative Dispute Resolution Business in Foreign Courts (Non-Litgation Alternatives Business Dispute Resolution), Journal Rechts Vinding Media National Legal Development, Vol 1 (2), Jakarta, pp. 280.

[7] Norman K. Denzin and Yonna S. Lincoln, 2009. Handbook of Qualitative Research, First edition, Student Library, Yogyakarta.

[8] Patton, Michael Quinn, 1990. Qualitative Evaluation and Research Methods, Sage Publications, New Delhi.

[9] Rachmadi Usman, (2003) Option Dispute Outside of Court, Citra Aditya Bakti, Bandung.

[10] Sarjita, (2005) Technique and Strategy of Land Dispute Resolution. Tugujogja Library, Yogyakarta.

[11] Joses Jimmy Sembiring, (2011). How to Resolve Dispute Out of Court (Negotiation, Mediation, Conciliation and Arbitration). Visimedia, Jakarta.

[12] Sugiyono, 2012. Qualitative and Quantitative Research Methods R \& D Mold to 16 Alfabeta, Bandung.

[13] Surojo, Irawan (2003). Capacity Land Law in Indonesia. Arkola, Surabaya.

[14] Sutiyoso, Bambang (2006). Business Dispute Resolution: Anticipation Solutions For Business Applicants Facing Dispute Present and Future. Citra Media, Yogyakarta. Bryman, A., 1988. Quantity and Quality in Social Research, London: Unwin Hyman.

[15] Wahyudi (2008). Conflict Management: A Practical Guide for Visionary Leader. Alfabeta Bandung. 